\title{
MODIFICATION OF ALKALOID STRUCTURE IN THE CONIUM DRUG WITH FULLERENES $\mathrm{C}_{60}$
}

\author{
M.A. ZABOLOTNYI, ${ }^{1}$ A.I. MOMOT, ${ }^{1}$ G.I. DOVBESHKO,${ }^{2}$ E.P. GNATYUK, ${ }^{2}$ \\ G.I. SOLYANYK,${ }^{3}$ O.P. DMYTRENKO, ${ }^{1}$ N.P. KULISH, ${ }^{1}$ K.V. FEDINA ${ }^{4}$ \\ ${ }^{1}$ Taras Shevchenko National University of Kyiv \\ (64, Volodymyrs'ka Str., Kyiv 01033, Ukraine; e-mail: Zabolotny@univ. kiev. ua) \\ ${ }^{2}$ Institute of Physics, Nat. Acad. of Sci. of Ukraine \\ (46, Nauka Ave., Kyiv 03680, Ukraine) \\ ${ }^{3}$ R.E. Kavetskyi Institute of Experimental Pathology, Oncology and Radiobiology \\ (45, Vasylkivska Str., Kyiv 03022, Ukraine) \\ PACS 33.15.Bh $\quad{ }^{4}$ A.A. Bogomolets National Medical University \\ (C) 2012 \\ (13, Taras Shevchenko Blvd., Kyiv 01033, Ukraine)
}

\begin{abstract}
The antineoplastic drug Conium, whose active components are piperidine alkaloids, and the possibility of a modification of its properties by fullerenes $\mathrm{C}_{60}$ are studied. The IR spectra of the mixture of the drug Conium and a fullerene water solution are obtained. The spectral manifestation of the formation of a complex of fullerene with one of the alkaloids, namely $\gamma$-coniceine, is detected. The existence of the complex and its spectral characteristics are confirmed by quantum-chemical computations with a Gaussian program. Moreover, the IR spectra are calculated, and the conformations of $\gamma$-coniceine are studied.
\end{abstract}

\section{Introduction}

Despite a rapid development of molecular biology and chemistry, which ensure a quick implementation of de novo synthesized drugs, plants remain to be a traditional rich source of pharmacologically active substances. In particular, almost a half of modern pharmaceuticals used in medicine were obtained from plant extracts. The same is absolutely true for antitumoral drugs as well. The list of effective antitumoral phytogenic drugs includes vincristine, vinblastine, etoposide, teniposide, taxol, taxotere, topotecan, irinotecan, and others. The main biologically active agents of plants used in medicine for treating the malignant neoplasms are alkaloids, which manifest a pronounced cytostatic action upon tumor cells. Recently, large interest was attracted to groups of alkaloids known as neurotoxins such as, e.g., terpenoids and piperidines. Some of their representatives (aconitine alkaloids of Aconitium napellus and poison hemlock (Conium maculatum) alkaloids) demonstrate a high antitumoral activity [1-4].
The experience in the application of antitumoral chemotherapy demonstrated that its capabilities are restricted, and the efficiency is low, if it is used for the treatment of locally invasive and disseminated forms of malignant neoplasms. In this case, a reduced efficiency of cytostatic therapy is associated with a low selectivity of the antitumoral action and a high toxicity with respect to the normal and, as a rule, vital organs and tissues. In this connection, the creation of effective and low-toxicity antitumoral drugs is one of the most actual challenging problems in modern oncology. It should be emphasized that the modification of pharmacological properties of the already known antitumoral agents aimed at enhancing their efficiency and/or reducing their toxicity is considered as a promising direction in the development of effective antitumoral drugs. The corresponding modification of antitumoral drugs can be based on changes of the structure and the properties of active ingredient molecules owing to the formation of complexes with fullerenes [5]. It is known that fullerene $\mathrm{C}_{60}$ molecules, due to their ability of inducing the charge transfer, are effective electron acceptors and are capable to essentially modify the structure of other molecules and form complexes with them. Therefore, this work is aimed at studying a possibility for Conium alkaloids to form a complex with fullerene $\mathrm{C}_{60}$ and at determining the energy and conformational parameters of the adducts of Conium alkaloids.

\section{Materials and Methods}

The analysis of a capability for alkaloid molecules to form adducts with fullerenes $\mathrm{C}_{60}$ was carried out, by 


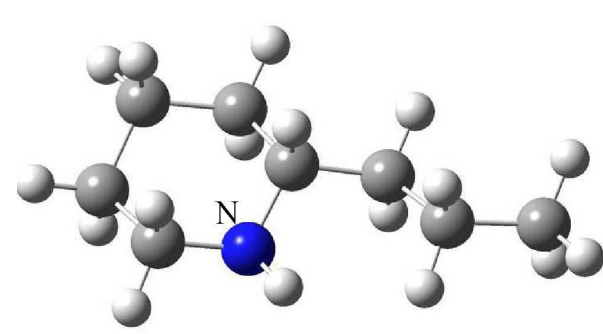

Coniine $\mathrm{C}_{8} \mathrm{H}_{17} \mathrm{~N}$

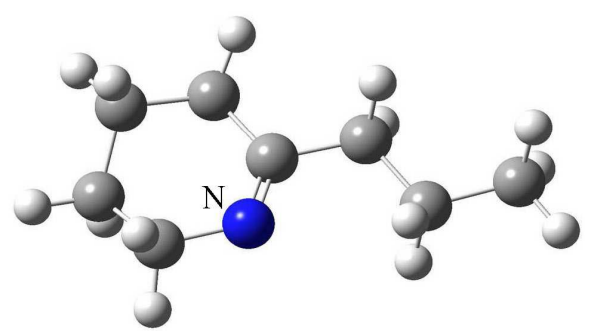

$\gamma$-coniceine $\mathrm{C}_{8} \mathrm{H}_{15} \mathrm{~N}$

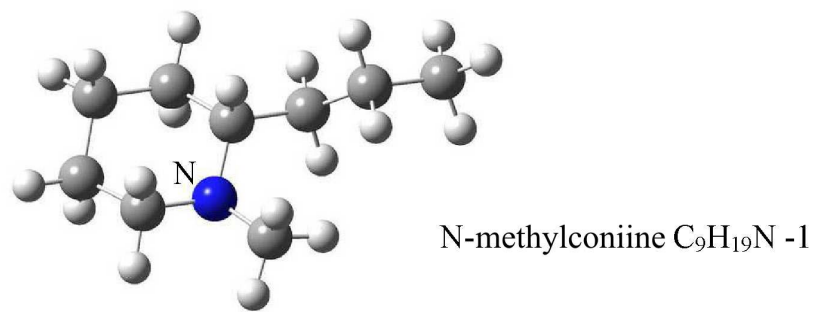

Fig. 1. Structural formulas of poison hemlock alkaloids

taking advantage of a numerical simulation and by analyzing the absorption spectra in the infra-red (IR) range. In the experimental researches, we used the Conium preparation (Conium maculatum D3, Weleda, Germany) and a $2 \%$ aqueous solution of fullerene $\mathrm{C}_{60}$ prepared at the Technical University (Ilmenau, Germany) [6]. The choice of Weleda's preparations was stimulated by the stability of their properties.

The mixtures of fullerene with Conium were prepared by mixing the initial substances in the following $\mathrm{C}_{60^{-}}$ to-Conium ratios: $0.2 \mathrm{ml}: 0.05 \mathrm{ml}, 0.2 \mathrm{ml}: 0.1 \mathrm{ml}$, and $0.2 \mathrm{ml}: 0.2 \mathrm{ml}$. Then the mixtures were stirred in an ultrasonic mixer for $30 \mathrm{~min}$.

All the specimens for recording the IR spectra were fabricated in the form of $\mathrm{KBr}$ pellets. The IR spectra were registered on an IR Fourier spectrometer Bruker IFS 66 (Germany) in the transmission geometry. The determination error for the wavenumber was $0.2 \mathrm{~cm}^{-1}$, the transmittance error was $0.1 \%$. The registration and the processing of spectra were carried out with the use of the software program OPUS 5.5.

Raman spectra for $\mathrm{C}_{60}$ were registered on a spectrometer Horiba Jobin-Yvon T64000 (France), by using the excitation emission of an Ar-Kr laser Stabilite 2018RM Spectra Physics 2.5W (USA) at a wavelength of $0.4888 \AA$.

The numerical analysis was carried out with the help of the software programs Gaussian 03, in the framework of the density functional method, and using the Becke 3parameter-Lee-Yang-Parr (B3LYP) hybrid functional with the basis set $6-31 \mathrm{G}(\mathrm{d})$.

\section{Research Results and Their Discussion}

It is known that poison hemlock (Conium maculatum) used for fabricating the Conium drug contains a number of alkaloids in its composition. Among those, the main alkaloids are coniine $\left(\mathrm{C}_{8} \mathrm{H}_{17} \mathrm{~N}\right), \mathrm{N}-$ methylconiine $\left(\mathrm{C}_{9} \mathrm{H}_{19} \mathrm{~N}\right)$, $\gamma$-coniceine $\left(\mathrm{C}_{8} \mathrm{H}_{15} \mathrm{~N}\right)$, conhydrine $\left(\mathrm{C}_{8} \mathrm{H}_{17} \mathrm{NO}\right)$, and pseudoconhydrine $\left(\mathrm{C}_{8} \mathrm{H}_{17} \mathrm{NO}\right)$ [7-10]. From the literature data, we also know about two conformational states of N-methylconiine. The calculations carried out for the dipole moment and the energy of alkaloid molecules in the ground states (Table 1) showed that three of six alkaloids ( $\gamma$-coniceine, conhydrine, and pseudoconhydrine) have molecules with higher dipole moments, which may result in the formation of adducts with the participation of just those molecules. The structural formulas of main alkaloids that are contained in poison hemlock are depicted in Fig. 1.

T a b l e 1. Dipole moments and ground-state energies of Conium alkaloids

\begin{tabular}{l|c|c}
\hline \multicolumn{1}{c|}{ Alkaloid } & $\begin{array}{c}\text { Dipole } \\
\text { moment, (Debye) }\end{array}$ & $\begin{array}{c}\text { Ground state } \\
\text { energy, } \\
\text { (Hartree units) }\end{array}$ \\
\hline Coniine & 0.82 & -369.8483 \\
N-methylconiine 1 & 0.44 & -409.1525 \\
N-methylconiine 2 & 0.46 & -409.1523 \\
$\gamma$-coniceine & 1.77 & -368.6375 \\
Conhydrine & 1.28 & -445.0555 \\
Pseudoconhydrine & 2.37 & -445.0576 \\
\hline
\end{tabular}




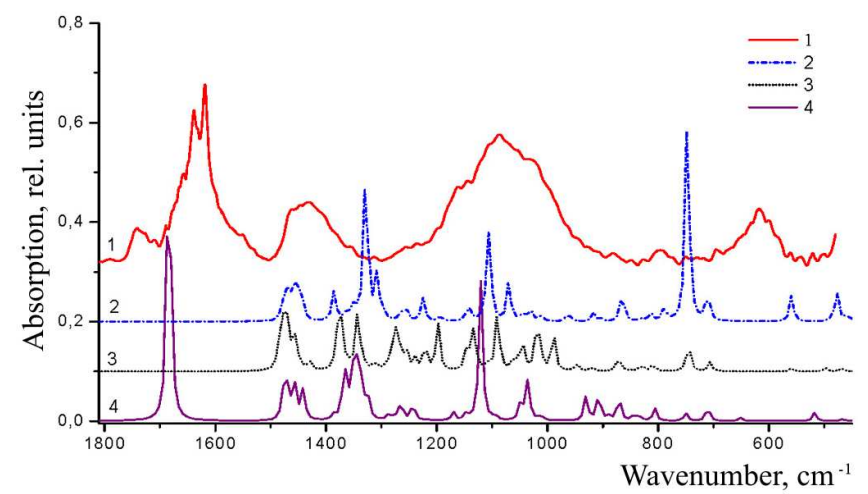

Fig. 2. Experimental IR spectrum for Conium drug (1) and calculated IR spectra for coniine (2), N-methylconiine (3), and $\gamma$ coniceine (4) molecules

The geometry of each alkaloid molecule was optimized, and the corresponding IR spectrum was calculated. A scaling factor of 0.9613 was used for the spectra.

In Fig. 2, the spectra of three alkaloids under consideration are exhibited. The bands in the high-frequency spectral range from 2800 to $3600 \mathrm{~cm}^{-1}$ are associated with stretching vibrations of $\mathrm{N}-\mathrm{H}$ and $\mathrm{C}-\mathrm{H}$ groups. In the range of $1800-400 \mathrm{~cm}^{-1}$, one can observe deformation vibrations of $\mathrm{C}-\mathrm{N}, \mathrm{C}-\mathrm{H}$, and $\mathrm{C}-\mathrm{C}$ bonds, stretching vibrations of double bonds $\mathrm{C}=\mathrm{C}$ and $\mathrm{C}=\mathrm{N}$, and $\mathrm{C}-$ $\mathrm{C}-\mathrm{C}$ skeletal vibrations. In the calculated spectrum of $\gamma$-coniceine, there is a band at $1684 \mathrm{~cm}^{-1}$, which corresponds to ring vibrations in the corresponding molecule; the dominant contribution to those vibrations can be given by the $\mathrm{C}=\mathrm{N}$ bond. In the spectra of other two alkaloids, no analogous band is observed.

The calculated alkaloid spectra qualitatively coincide with the experimental spectrum of IR absorption by Conium (curve 1 in Fig. 2). The presence of peaks in the experimental spectrum in the interval of about 1600$1800 \mathrm{~cm}^{-1}$ testifies to the presence of $\gamma$-coniceine in the Conium drug. The presence of coniceine can be determined from the Raman spectrum, since the calculations point to the presence of the $3369-\mathrm{cm}^{-1}$ line associated with vibrations of the $\mathrm{N}-\mathrm{H}$ bond.

Of particular interest is $\gamma$-coniceine. It is a unique alkaloid among those entering the Conium content, because it possesses a double bond connecting $\mathrm{N}$ and $\mathrm{C}$ atoms (Fig. 1). The presence of a double bond in $\gamma$ coniceine may testify that this alkaloid can form stable chemical complexes.

The numerical analysis executed with the help of the software program Gaussian showed that $\gamma$-coniceine has at least six stable conformations, the structural formulas of which are presented in Fig. 3. Conformations 1 to 4 ,
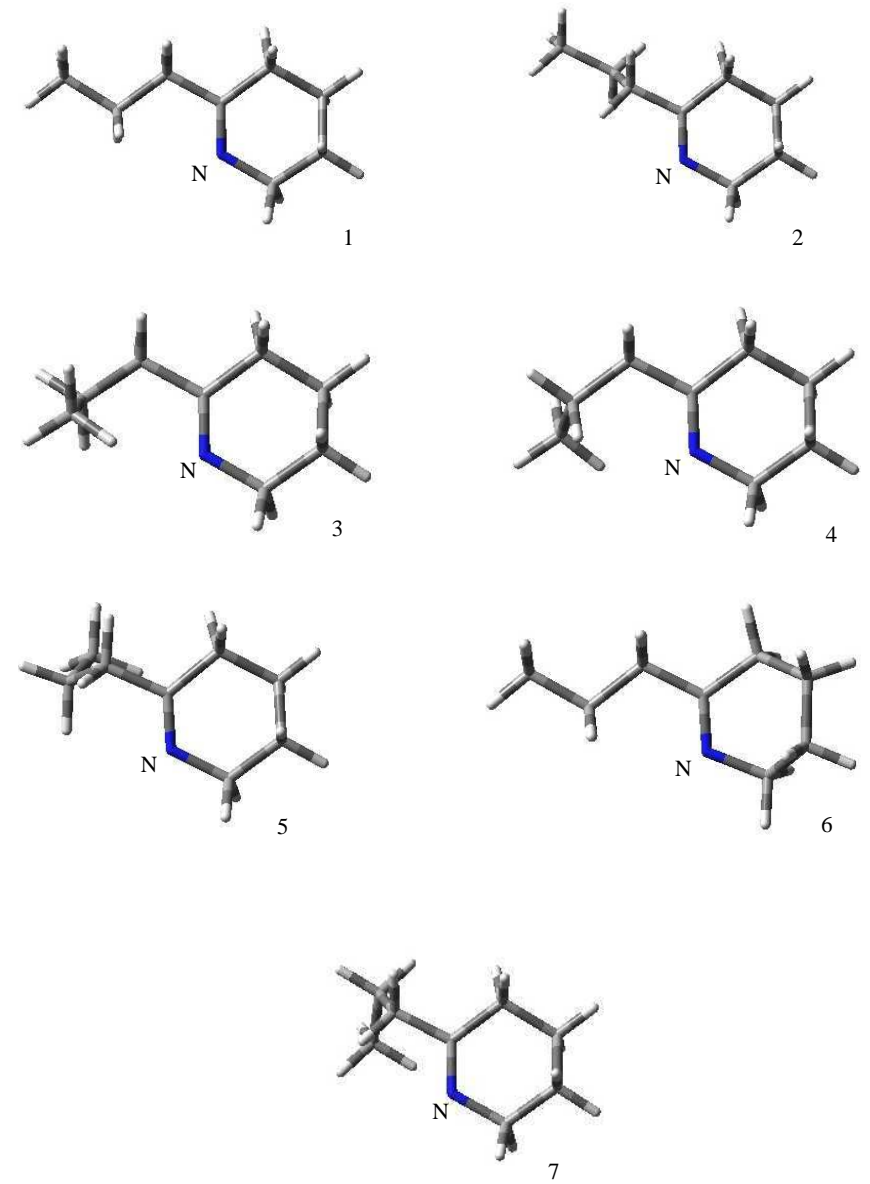

Fig. 3. Conformational forms of $\gamma$-coniceine molecule

6 , and 7 are stable (the frequencies of their vibrations are real-valued numbers), whereas conformation 5 is unstable (there is one imaginary vibration frequency) (see Table 2). The molecule in conformation 1 has the lowest energy in the ground state, $E_{1}=-368.6375$ Hartree. Our calculations show that the structure with the lowest energy has the largest linear dimensions among all possible ones and the lowest dipole moment among stable states. Hence, $\gamma$-coniceine molecules in state 1 should dominate in the solution in the equilibrium case, which explains the particular interest in this alkaloid.

In Fig. 4, the infra-red spectra obtained for two conformers of $\gamma$-coniceine characterized by minimal energies are compared. One can see that the spectra are different in both the band positions and intensities.

In the experimental IR spectrum of fullerene solution, four narrow absorption bands are observed at 527, 576, 1182 , and $1429 \mathrm{~cm}^{-1}$, which confirms the nature of the initial specimen. In the IR spectrum, the bands stem from intramolecular vibrations of the four-fold degener- 
T a b l e 2. Parameters of a $\gamma$-coniceine molecule in various conformational states

\begin{tabular}{|c|c|c|c|c|c|c|}
\hline State & $E-E_{1}, \mathrm{eV}$ & $\begin{array}{l}\text { Number } \\
\text { of imaginary } \\
\text { frequencies }\end{array}$ & $\begin{array}{c}\text { Dipole } \\
\text { moment }\end{array}$ & $\begin{array}{c}\text { Maximum } \\
\text { linear } \\
\text { size, } \AA\end{array}$ & $\begin{array}{l}\text { Position } x_{i} \text { of the } \\
\text { peak corresponding to } \mathrm{C}=\mathrm{N} \\
\text { vibrations in the } \mathrm{IR} \text { spectrum, } \\
\qquad \mathrm{C}=\mathrm{N}, \mathrm{cm}^{-1}\end{array}$ & $\begin{array}{c}\text { Peal } \\
\text { position } \\
\text { difference } \\
x_{i}-x_{1}, \mathrm{~cm}^{-1}\end{array}$ \\
\hline 1 & 0 & 0 & 1.77 & 8.37 & 1684 & 0 \\
\hline 2 & 0.034 & 0 & 1.78 & 8.30 & 1678 & -5.28 \\
\hline 3 & 0.022 & 0 & 1.84 & 7.55 & 1686 & 1.94 \\
\hline 4 & 0.028 & 0 & 1.88 & 7.60 & 1685 & 1.16 \\
\hline 5 & 0.134 & 1 & 1.92 & 8.25 & 1666 & -18.01 \\
\hline 6 & 0.053 & 0 & 1.79 & 7.25 & 1675 & -8.37 \\
\hline
\end{tabular}

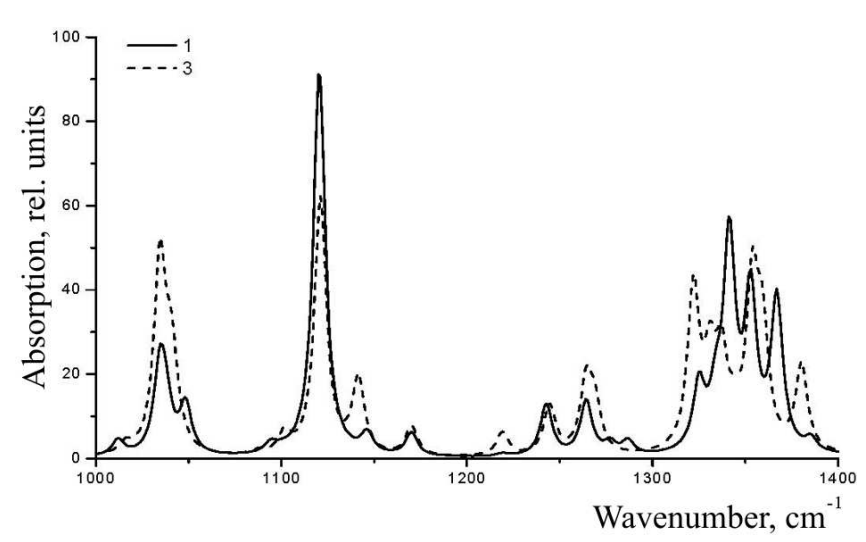

Fig. 4. Comparison between IR spectra calculated for conformers 1 (solid curve) and 3 (dashed curve) of $\gamma$-coniceine. Conformer enumeration corresponds to that in Table 2

ate IR-active mode $T_{1 u}$. The band at $576 \mathrm{~cm}^{-1}$ is less sensitive to the action of external factors. The mode at $1182 \mathrm{~cm}^{-1}$ characterizes the intermolecular distance, and a frequency of $1429 \mathrm{~cm}^{-1}$ is sensitive to the influence of a charge. The latter two modes belong to stretching vibrations, with the vibrations of single bond $\mathrm{C}-\mathrm{C}$ being observed at about $1183 \mathrm{~cm}^{-1}$, and those of the double bond $\mathrm{C}=\mathrm{C}$ at about $1426 \mathrm{~cm}^{-1}$. In addition, there are two bands of valence $\mathrm{OH}$ vibrations in the interval of $3500-3400 \mathrm{~cm}^{-1}$, which correspond to stronger (at $3520 \mathrm{~cm}^{-1}$ ) and weaker (at $3415 \mathrm{~cm}^{-1}$ ) hydrogen bonds.

In the Raman spectra, vibrations typical of $\mathrm{C}_{60}$ are also observed (Fig. 5). In the Raman spectrum, the marker lines of fullerene at 1574, 1466, 1424, 1250, 1100, $774,707,493$, and $270 \mathrm{~cm}^{-1}$ [11] are registered.

The experimental spectrum of Conium (Fig. 6) reveals three bands of stretching $\mathrm{OH}$ vibrations (at 3547, 3469, and $3417 \mathrm{~cm}^{-1}$ ), a band in a vicinity of $3250 \mathrm{~cm}^{-1}$ related to $\mathrm{NH}$ vibrations, and two bands at 1639 and $1619 \mathrm{~cm}^{-1}$ corresponding to $\mathrm{C}=\mathrm{N}$ valence vibrations. The experimental data agree with the results

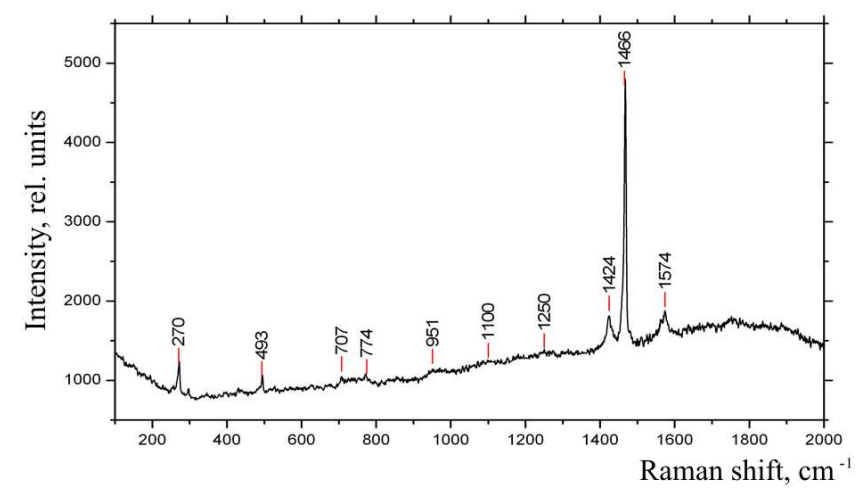

Fig. 5. Raman spectrum of fullerene deposited from an aqueous solution onto a gold substrate

of calculations obtained within quantum chemical methods.

After the complex of Conium with fullerene having been formed, a band at $1633 \mathrm{~cm}^{-1}$ appeared in the spectrum instead of two bands in the interval 1600$1700 \mathrm{~cm}^{-1}$. This fact may testify to the interaction between $\mathrm{C}_{60}$ and the drug and to the formation of a new bond, most likely in $\gamma$-coniceine. In the interval 3500$3400 \mathrm{~cm}^{-1}$, only one maximum at $3435 \mathrm{~cm}^{-1}$ remains. In specimens with a smaller amount of fullerene, all those bands become somewhat weakened, but do exist. If the content of fullerene in the studied specimen increases e.g., $0.05 \mathrm{ml}$ Conium $+0.2 \mathrm{ml} \mathrm{C}_{60}$ - they disappear completely. The bands associated with fullerene do not almost change, although the complex demonstrates a certain shift of the fullerene bands toward high frequencies by about $0.5-1.2 \mathrm{~cm}^{-1}$.

In Fig. 7, the concentration dependences of IR spectra for the complex Conium + fullerene $\mathrm{C}_{60}$ are depicted. The experimental data demonstrate that, if the Conium-to-fullerene content ratio is 1:1 (the lower curve), a spectrum typical of the pure Conium drug is observed, namely, a double band in the region of 1639 $1619 \mathrm{~cm}^{-1}$ and three vibrational states at 3549,3470 , 


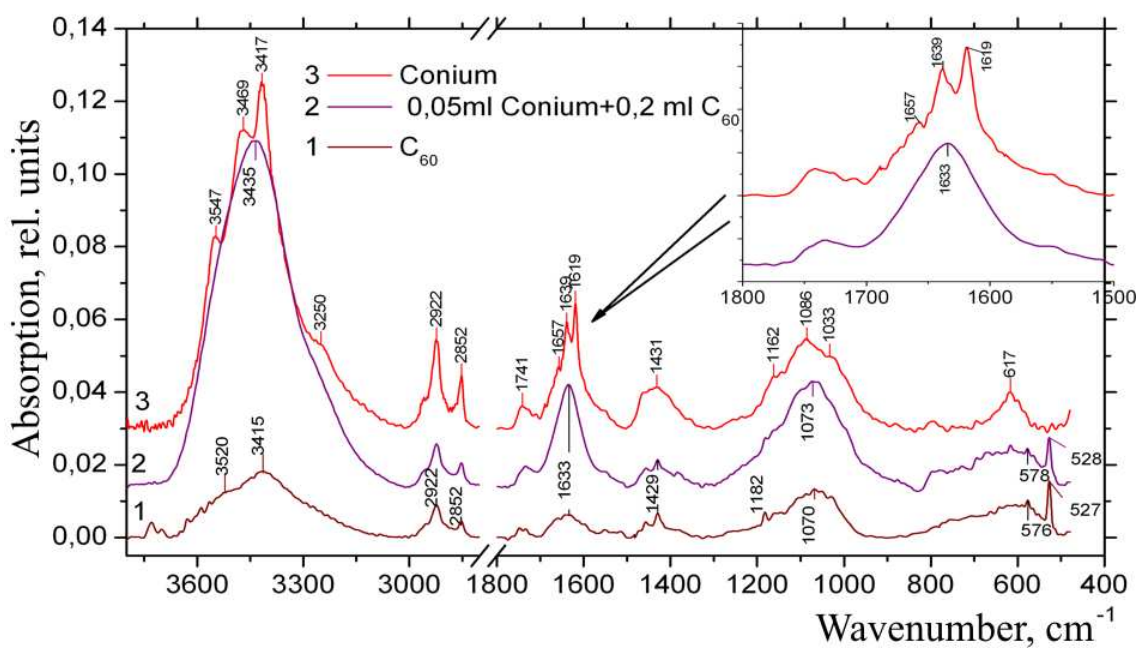

Fig. 6. IR Fourier spectra of Conium drug, fullerene, and a complex of Conium with fullerene

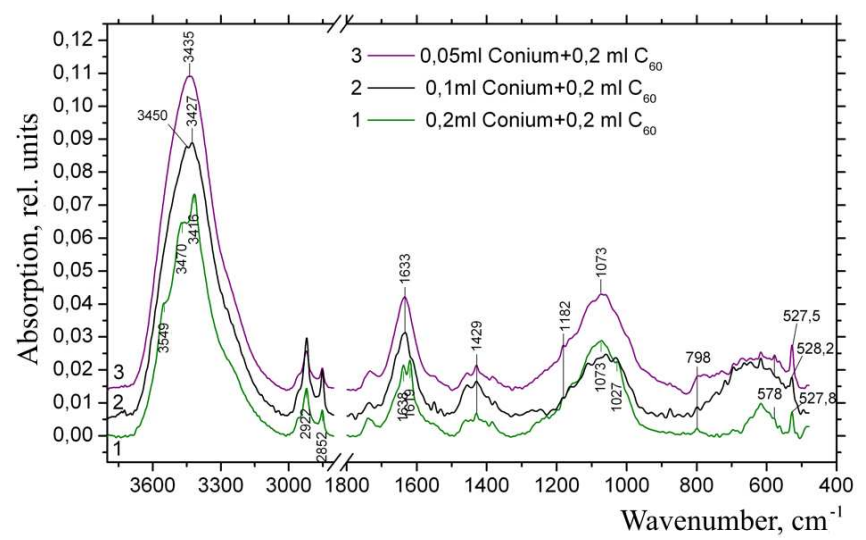

Fig. 7. IR spectra of the complex "fullerene + Conium drug" taken in various contents

and $3416 \mathrm{~cm}^{-1}$ in the region of hydrogen bonds. The fullerene marker bands at $1429,1182,578$, and $528 \mathrm{~cm}^{-1}$ are also present. If the Conium content decreases and, respectively, the mass of fullerene grows (the middle and upper curves), the splitting disappears, and only one maximum remains in the interval around $3435 \mathrm{~cm}^{-1}$ and another one in the interval around $1633 \mathrm{~cm}^{-1}$, with the fullerene bands becoming more intense and pronounced.

Our calculations showed that the formation of a stable complex consisting of one $\gamma$-coniceine and one fullerene $\mathrm{C}_{60}$ molecules is possible, which is exhibited in Fig. 8. This figure illustrates a deformation-induced modification of $\gamma$-coniceine molecule with respect to conformation 1 , which is the most favorable energetically (see Table 2), during the formation of the complex. The structure depicted in Fig. 8 was obtained by optimizing the

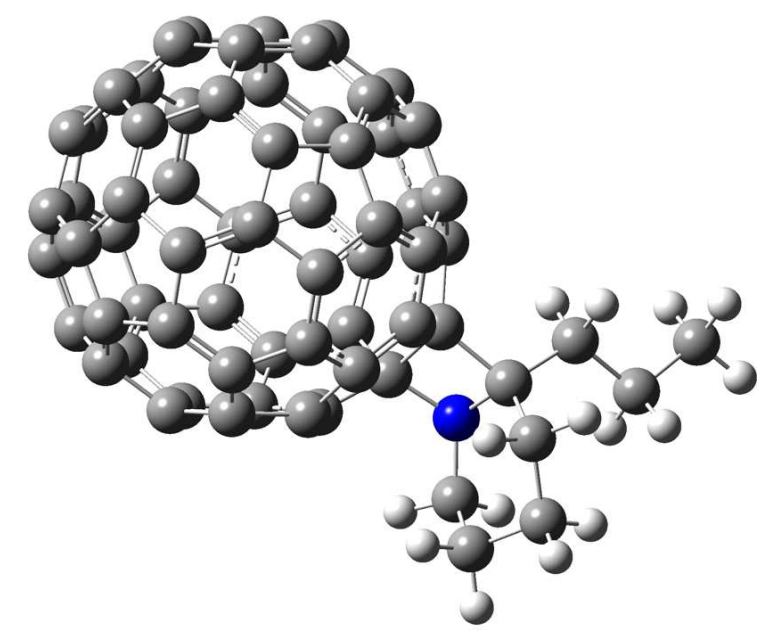

Fig. 8. Molecular complex " $\gamma$-coniceine $+\mathrm{C}_{60}$ "

complex geometry in the framework of the Hartree-Fock method with the basis $3-21 \mathrm{G}$. The stability of the determined structure is confirmed by the absence of the so-called imaginary frequencies in the calculated vibration spectrum. In Table 4, the data for the ground-state energy of the complex (taking the energy of zero-point oscillations into account) and the sum of the energies of a $\gamma$-coniceine molecule in conformational state 1 and a fullerene molecule are presented. These data allowed the binding energy of the complex to be determined.

It is known that the Hartree-Fock method does not take the energy of electron correlation into account. Therefore, the energy was calculated using the same density functional method (B3LYP) in the basis 6-31G(d). As is seen from Table 4, the binding energy calculated 
T a b l e 3. Frequencies in the IR spectrum and vibration relationships for $\mathrm{C}_{60}$, Conium, and complex " $\mathrm{C}_{60}+$ Conium"

\begin{tabular}{|c|c|c|c|c|c|}
\hline Conium & $\mathrm{C}_{69}$ & $\begin{array}{c}0.2 \text { Conium } \\
+0.2 \mathrm{C}_{60}\end{array}$ & $\begin{array}{c}0.1 \text { Conium } \\
+0.2 \mathrm{C}_{60}\end{array}$ & $\begin{array}{c}0.05 \text { Conium } \\
+0.2 \mathrm{C}_{60}\end{array}$ & Vibration relationship \\
\hline 3547 & 3520 & 3549 & 3450 & & OH stretching hydrogen-bonded \\
\hline 3469 & & 3470 & 3427 & 3435 & OH stretching hydrogen-bonded \\
\hline 3417 & 3415 & 3416 & & & OH stretching hydrogen-bonded \\
\hline 3250 & & & & & OH stretching hydrogen-bonded \\
\hline 2922 & 2922 & 2922 & 2922 & 2922 & $\mathrm{CH}$ asymmetric stretching \\
\hline 2852 & 2852 & 2852 & 2852 & 2852 & $\mathrm{CH}$ symmetric stretching \\
\hline \multirow[t]{2}{*}{1741} & 1748 & & & & $\mathrm{C}=\mathrm{O}$ \\
\hline & 1733 & 1738 & 1735 & 1733 & $\mathrm{C}=\mathrm{O}$ \\
\hline 1639 & 1633 & 1638 & 1633 & 1633 & $\mathrm{C}=\mathrm{N}, \mathrm{C}=\mathrm{C}, \mathrm{N}-\mathrm{H}$ \\
\hline 1619 & & 1619 & & & $\mathrm{C}=\mathrm{N}, \mathrm{C}=\mathrm{C}, \mathrm{N}-\mathrm{H}$ \\
\hline 1431 & 1429 & 1429 & 1429 & 1429 & $\mathrm{C}_{60}$ marker band \\
\hline 1162 & 1182 & 1181 & 1182 & 1181 & $\mathrm{C}_{60}$ marker band \\
\hline 1086 & & 1073 & 1060 & 1073 & $\mathrm{C}-\mathrm{C}, \mathrm{C}-\mathrm{O}$ \\
\hline 1033 & & 1027 & 1032 & & $\mathrm{C}-\mathrm{C}, \mathrm{C}-\mathrm{O}$ \\
\hline & 798 & 798 & 798 & 798 & $\mathrm{C}-\mathrm{C}-\mathrm{C}$ \\
\hline \multicolumn{6}{|l|}{617} \\
\hline & 576 & 578 & 578 & 578 & $\mathrm{C}_{60}$ marker band \\
\hline & 527 & 527.8 & 528.2 & 527.8 & $\mathrm{C}_{60}$ marker band \\
\hline
\end{tabular}

T a b l e 4. Parameters of complex " $\gamma$-coniceine $+\mathbf{C}_{60}$ "

\begin{tabular}{|c|c|c|c|c|c|c|c|}
\hline \multirow{2}{*}{$\begin{array}{l}\text { Optimization and vibration } \\
\text { calculation method }\end{array}$} & \multirow{2}{*}{$\begin{array}{c}\text { Ground state energy } \\
\text { calculation } \\
\text { method }\end{array}$} & \multicolumn{4}{|c|}{ Ground state energy, Hartree } & \multicolumn{2}{|c|}{ Binding energy } \\
\hline & & Fullerene $\mathrm{C}_{60}$ & $\gamma$-coniceine & $\begin{array}{c}\text { Total } \\
\mathrm{C}_{60}+\gamma \text {-con. }\end{array}$ & $\begin{array}{c}\text { Complex } \\
\mathrm{C}_{60}+\gamma \text {-con. }\end{array}$ & Hartree & $\mathrm{eV}$ \\
\hline Hartree-Fock $3-1 \mathrm{G}$ & Hartree-Fock 3-21G & -2258.6720 & -363.8687 & -2622.5407 & -2622.5412 & 0.00059 & 0.0160682 \\
\hline \multirow[t]{2}{*}{ Hartree-Fock 3-21G } & & & & & & & \\
\hline & functional $6-31 \mathrm{G}(\mathrm{d})$ & -2285.7585 & -368.4131 & -2654.1716 & -2654.1711 & -0.00046 & -0.012614 \\
\hline Density & & & & & & & \\
\hline functional 6-31G(d) & functional 6-31 $\mathrm{G}(\mathrm{d})$ & -2285.7990 & -368.4172 & -2654.2162 & -2654.1954 & -0.02083 & -0.566923 \\
\hline
\end{tabular}

by different techniques has different signs. Therefore, in order to specify data, the optimization of a complex geometry and the calculation of the corresponding frequencies were carried out in the framework of the density functional method (B3LYP) in the basis 6-31G(d). This more exact calculation confirmed the stability of the complex. At the same time, it was found that, for the complex to be formed, an energy barrier has to be overcome.

One can see from Fig. 9 that the calculated spectrum of the complex $\gamma$-coniceine + fullerene $\mathrm{C}_{60}$ contains marker bands of fullerene subjected to a definite low-frequency shift in comparison with the experimental fullerene spectrum (Fig. 6, curve 1). In the calculated infra-red spectrum of the complex, there is no band at $1684 \mathrm{~cm}^{-1}$, which is characteristic of $\gamma$-coniceine and produced by vibrations of the $\mathrm{C}=\mathrm{N}$ double bond. This circumstance is evidently associated with the hybridiza- tion of the state connected with ring vibrations in $\mathrm{C}_{60}$ of coniceine, when the complex is formed.

Hence, we demonstrated a capability of modifying the conformational parameters of Conium alkaloids with the use of fullerene $\mathrm{C}_{60}$. Such a modification of the conformational characteristics of Conium alkaloids can substantially affect the pharmacological properties of the drug, so that additional researches in this direction are needed.

\section{Conclusions}

1. The structural forms of alkaloids entering the Conium content-coniine, N-methylconiine, $\gamma$-coniceine, conhydrine, and pseudoconhydrine-have been determined, and the dipole moments and ground-state energies of corresponding molecules have been calculated. The conformations of alkaloid molecules with minimum energy 


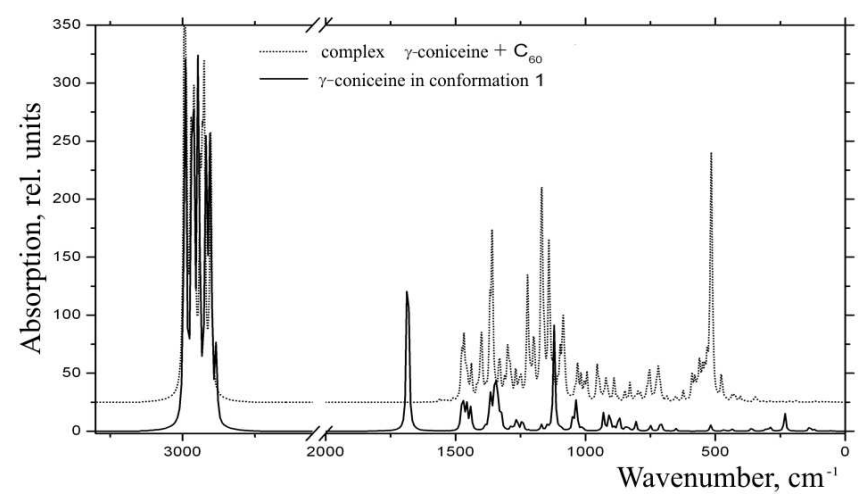

Fig. 9. Calculated IR spectra for $\gamma$-coniceine in conformation 1 (solid curve) and the complex " $\gamma$-coniceine $+\mathrm{C}_{60}$ " (dotted curve)

were found to have the largest linear dimensions and the lowest (for stable states) dipole moments.

2. The spatial structure and the energy parameters of stable and unstable conformations of a $\gamma$-coniceine molecule have been determined. The IR absorption spectra for two molecular conformations of $\gamma$-coniceine with the lowest energies have been calculated. It is shown that the absorption in the interval around $1684 \mathrm{~cm}^{-1}$, which is connected with vibrational modes of $\mathrm{C}=\mathrm{N}$ molecular groups is inherent to only one conformation.

3. Our experimental data confirm that the features in the vibrational modes of the Conium drug are also associated with the presence of $\mathrm{C}=\mathrm{N}$ groups and are located in the region of $1700-1500 \mathrm{~cm}^{-1}$.

4. A possibility for $\gamma$-coniceine and fullerene $\mathrm{C}_{60}$ to form a complex has been demonstrated.

1. M. Kondoh, I. Suzuki, F. Nagashima, S. Simizu, M. Harada, M. Fujii, H. Osada, Y. Asakawa, and Y. Watanabe, J. Pharm. Exper. Therapy 311, 115 (2004).

2. G.I. Solyanyk, O.G. Fedorchuk, O.M. Pyaskovska, O.Y. Dasyukevych, G.V. Gorbyk, and D.L. Kolesnyk, Patent 48524 Ukraine, MPK A 61 K 35/76, A 61 P 35/04. No. 2009 08954; appl. 28.08.2009; publ. 25.03.2010, Bull. $\mathrm{N} 6$.

3. O.N. Pyaskovskaya, Yu.V. Yanish, D.L. Kolesnik, O.I. Dasyukevich, V.A. Shlyakhovenko, and G.I. Solyanik, Biofiz. Visn. 21, No. 2, 35 (2008).
4. N.N. Aleutskii, N.A. Nazarenko, E.V. Rekhacheva, N.V. Solovyova, E.V. Karpova, Patent 4042544/14 Russia, publ. 20.09.1996.

5. M.A. Zabolotnyi, N.V. Bashmakova, Yu.M. Barabash, G.I. Dovbeshko, L.N. Kirkilevskaya, E.P. Gnatyuk, O.P. Dmitrenko, M.P. Kulish, and A.I. Momot, in Abstracts of the 2nd International Scientific Conference "Nanostructure materials-2010: Belarus-RussiaUkraine" (Kyiv, 2010), p. 677 (in Russian).

6. S. Thakral and R.M. Mehta, Indian J. Pharm. Sci. 68, 13 (2006).

7. A.K. Sirotkin, L.B. Piotrovskii, L.N. Poznyakova, and O.I. Kiselev, Vopr. Biolog. Med. Farmats. Khim. No. 3, 21 (2005).

8. A.P. Orekhov, Chemistry of Alkaloids (Khimiya, Moscow, 1995) (in Russian).

9. F.D. Galey, D.M. Holstege, and E.G. Fisher, J. Vet. Diagn. Invest. 4, 60 (1992).

10. S.T. Lee, B.T. Green, K.D. Welch, J.A. Pfister, and K.E. Panter, Chem. Res. Toxicol. 21, 2061 (2008).

11. G.V. Andrievsky, V.K. Klochkov, A.B. Bordyuh, and G.I. Dovbeshko, Chem. Phys. Lett. 364, 8 (2002).

Received 06.10.11.

Translated from Russian by O.I. Voitenko

\section{МОДИФІКАЦІЯ СТРУКТУРИ АЛКАЛОЇДІВ} ПРЕПАРАТУ СОNIUМ ФУЛЕРЕНАМИ $\mathrm{C}_{60}$

М.А. Заболотний, А.І. Момот, Г.І. Довбешко,

О.П. Гнатюк, Г.І. Соляник, О.П. Дмитренко,

М.П. Куліш, К.В. Федіна

Р е з ю м е

Проведено дослідження протипухлинного препарату Conium, активними компонентами якого є алкалоїди пиперидинової групи, і можливості модифікації його властивостей за допомогою фулеренів $\mathrm{C}_{60}$. Виконано вимірювання спектрів ІЧ поглинання суміші препарату Conium і водного розчину фулеренів. Виявлені спектральні особливості утворення комплексу фулерену з одним з алкалоїдів, а саме $\gamma$-коніциїном. Існування такого комплексу і його спектральні характеристики підтверджуються квантово-хімічними обчисленнями, виконаними за допомогою програми Gaussian. Крім того, обчислено IЧ-спектри алкалоїдів і досліджено конформації $\gamma$-коніциїну. 